\title{
6. バイオテクノロジー
}

\section{（2） 放射線照射利用 ${ }^{\dagger}$}

\author{
天野悦夫 \\ 福井県立大学生物資源学部生物資源開発研究センター \\ 910-4103 福井県坂井郡芦原町二面 88-1
}

Key Words : radiation utilization, mutation breeding, sterile insect technique, insect pest eradication, food irradiation

\section{はじめに}

本稿の対象期間として，1981年からの20年が 依頼されてきた。この期間は筆者が, 三島の国 立遺伝学研究所（文部省）から, 茨城県大宮町 所在の農業生物資源研究所放射線育種場（農林 水産省）に, さらに農水省派遣職員として, 国 際原子力機関（IAEA）に赴任していた時期に 当たる。その後現職の公立大学に奉職している が, 特にIAEA 勤務を含めた後半期は広く放 射線利用の仕事に関与してきた。個人的には放 射線取扱主任者として，また放射線育種場勤務 時にはガンマーフィールドの線源交換などで日 本アイソトープ協会にはずいぶんお世話になっ た。本稿では直接の協会との関係を離れて, 生 物・農学分野での放射線照射利用について述べ るが，この場で協会への感謝を記しておきたい。

生物・農業関連の放射線照射利用では(1)突然 変異利用の作物育種, (2)不妊虫放飼による害虫 駆除，(3)滅菌殺虫等を目的とした食品照射の主 要分野がある。原子力技術の平和利用の一つと して, ウィーンにある国際原子力機関 (IAEA)

\footnotetext{
${ }^{\dagger}$ 6. Biotechnology. (2) Radiation Utilization as Biotechnology. Etsuo AMANO : Faculty of Biosciences, Fukui Prefectural University, Biological Resources Research and Development Centre, 88-1 Futaomote, Awara-cho, Sakai-gun, Fukui Pref. 910-4103, Japan.
}

には，ローマに本部がある国連食糧農業機構 (FAO) との共同部門があって，世界の情報の 収集と発展途上国向けの研究推進をしている。 この共同部門 (Joint FAO/IAEA Division)の中 には土壤科学や畜産部門もあるが，ここではわ が国で大きな成果があり，またこれからが期待 される上記 3 分野について述べる。

旧科学技術庁予算によって平成11年と同 12 年 にわたって，放射線技術の経済効果を調査する プロジェクトがあり，筆者は突然変異育種関連 で参加した。原子力利用の総合分野ではわが国 の場合, 放射線技術の工業, 医学, 農業利用の 3 分野の合計は原子力発電を上回る $54 \%$ になっ た。そのなかで，半導体分野などで総額 7 兆 3 千億円に達して 3 分野の $85 \%$ を占める圧倒的な 比率となった工業分野に対し, 研究用の RIを 含めても生物・農業分野のシェアは 1 千億円強 のわずか $1 \%$ という通貨価額数值になった1),2)。

しかし，この分野では価額上の数值では評価 できない要素がある。半導体などの工業製品は 工場を出ると，たとえ修理されても後は消耗さ れるのみであり，また医学利用ではその患者に とってはこの上ない救いであったとしても，や はり寿命は尽きる。これに対して，突然変異遺 伝子の利用では，成功した照射は 5 年から 10 年 以前のただ 1 回だけであっても，その成果は農 家の庭先での増殖も可能であり，交配育種に利 
用されるとその寿命は無限である。また小笠原 諸島，奄美諸島，沖縄諸島におけるミカンコミ バエやウリミバエの駆除は, 農業生産物の直接 的な増加はわずかでも，これらの害虫のために 設定されていた検疫による本土との格差が永続 的になくなることは，その地域にとってはこの 上なく好ましい質的成果であろう。食品照射で は，わが国ではジャガイモの発芽抑制のための 軽度の照射が世界に先駆けて実施されている。 しかし, 環境に放出される化学物質がオゾンホ ールの拡大につながるとして各種の有害物質が 問題になっている昨今, 検疫や殺虫, 滅菌の主 要手段である臭化メチルが禁止されたときの代 替手段としては，放射線照射がおそらく唯一の 代替技術になるであろう。このような立場でそ れらの技術の現状を述べたい。

\section{1. 实然変異育程}

生物に放射線を照射すると突然変異が誘発さ れ，それらが安定に遺伝することは1920年代に

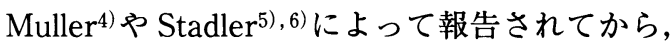
特に原子力の時代となった1950年頃からは農作 物の品種改良への応用が進み始めた。前記 IAEA の小出版物7),9)に公表されてきた世界の 突然変異品種の中でもっとも早い物は1934年に インドネシアで発表されたタバコの品種 「Chlorina F1」で，これは1930年に親系統 Volstenland にX 線を照射して得られた物であ $3^{8)}$ 。この場合は単に歴史上の一粅であるとし ても，第二次大戦後に $\gamma$ 線源が広く使えるよ うになってからはわが国の水稲で，フジミノリ の $\gamma$ 線照射によって選抜育成され, 新しい育種 法の黎明であるとして命名された「レイメイ」 の特性はその後も多くの子孫品種に引き継がれ ていまだに健在である10),11)。レイメイに遅れ ること 10 年ほどで米国の $\gamma$ 線照射による突然変 異品種「Calrose 76」も耐倒伏性要素の半矮性 誘発遺伝子が引き続き交配育種に使われてい $3^{3), 7) 。}$

このような単なる永続性だけでなく，パキスタン
では高収量性で早生のワ夕品種「NIAB-78」12) の育成，普及によって，木綿の輸入国から一転 して綿花の輸出国になったという一国の経済を 変えた例もある。筆者はIAEA から公表され てきた突然変異法による世界の品種を自作のデ ータベースに作って維持してきているが，それ からキーワード検索によって作成した世界の国 別，作物別を表 1 に示す。

上記のデータベースは詳細が IAEA の出版 物7)，8)に公表されたものに限定しているが，突 然変異法で育成された世界の品種は，平成13年 1 月からはIAEA の担当課から直接データべ 一スとして公表されるようになったア)。それに よれば，世界での累計では現在は 2200 品種を 超えている。ここに示した表ではまだ累計総数 は2000 品種に届いていないが，それでも多少 のお国ぶりが読みとれる。世界でのトップは中 国であるが，1986年になって生活に潤いを与え るバラやカンナで 7 品種など花き類が出始めた が，それまでは食用作物が中心であった。これ は世界の花屋として活動しているオランダとは 対照的である。オランダでは穀類に品種が出た のは最近の醸造用大麦(間接利用)だけである ${ }^{13)} 。$ 中国の場合は品種数では旧ソ連とともに多数あ るが，雑種種子の照射処理など，その詳細には 問題を感じるものが少なくない。特に, レーザ 一照射での誘発は他の国からは旧ソ連の 1 例の みであり ${ }^{14)}$ ，また雑種種子の使用，レーザー種 別，照射線量についてなど，問題を感じるのは 残念である。一方で平成13年春に米国農務省の 遺伝資源データベースイで検索調查してみたと ころ，米国では小麦，大麦，菜豆，稲などで突 然変異体が交配育種に組み込まれて多くの品種 を出していながら，それらの情報がIAEAに は届いていなかった。これらを加えると東西統 一されたドイツを超して米国は第 5 位になるで あろう。

上記の放射線技術の経済効果調査では農業分 野の中では総額 1 179億円のうち, 突然変異育 種の成果は水稲を中心に 973 億円に達し, 農業 
表 1 突然変異法によって育成された世界の変異品種

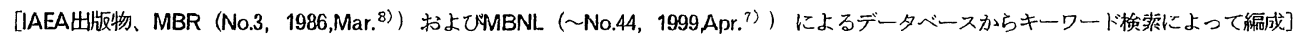

\begin{tabular}{|c|c|c|c|c|c|c|c|c|c|c|c|c|c|c|c|c|c|c|c|c|c|c|c|}
\hline \multirow{3}{*}{\multicolumn{2}{|c|}{$\begin{array}{l}: \\
: \text { 品 } \\
: \text { 種 } \\
: \\
:\end{array}$}} & \multirow{3}{*}{$\begin{array}{l}\text { 交配 } \\
\text { 利用 }\end{array}$} & \multicolumn{15}{|c|}{ 作物 } & \multirow{2}{*}{\multicolumn{5}{|c|}{ 妿異原" }} & \multirow{3}{*}{ 偳考" } \\
\hline & & & \multicolumn{4}{|c|}{ 踓類 } & \multicolumn{2}{|c|}{ : } & 豆頪 & & & 裸賞用 & & & 頻 & $z \sigma$ & & & & & & & \\
\hline & & & : 稲 & 大麦 & 小麦以 & לבחסן & 他: & 大豆 & 潒豆 & 他 & 药 & 花物 & 槊物： & 木本 & 草本 & : 㧴維 & & $x$ & $G$ 中 & 中性子 & 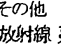 & 豚湖 & \\
\hline & 314 & 73 & 117 & 1 & 81 & 23 & 4 & 23 & 0 & 26 & 0 & 7 & 0 & 3 & 2 & 8 & 22 & 9 & 218 & 17 & 2 & 3 & las 14 \\
\hline インド & 253 & 42 & 35 & 14 & 4 & 0 & 5 & 0 & 3 & 35 & 46 & 57 & 0 & 1 & 9 & 13 & 31 & 28 & 145 & 7 & 5 & 26 & ctr 8 \\
\hline 须(旧ソ速) & 209 & 72 & 6 & 28 & 36 & 12 & 12 & 9 & 4 & 30 & 17 & 7 & 1 & 9 & 4 & 4 & 30 & 1 & 56 & 0 & 5 & 86 & las 1 \\
\hline オランダ & 176 & 1 & 0 & 1 & 0 & 0 & 0 & 0 & 0 & 0 & 80 & 93 & 0 & 0 & 0 & 0 & 2 & 153 & 17 & 5 & 1 & 3 & \\
\hline ドイツ & 140 & 48 & 0 & 46 & 2 & 0 & 2 & 1 & 2 & 1 & 34 & 45 & 0 & 1 & 0 & 0 & 6 & 57 & 2 & 0 & 1 & 5 & \\
\hline 日本 & 120 & 43 & 46 & 8 & 2 & 0 & 1 & 6 & 0 & 1 & 14 & 9 & 8 & 4 & 4 & 3 & 14 & 2 & 74 & 0 & 2 & 4 & ctr 16 \\
\hline 米国 & 105 & 51 & 23 & 11 & 3 & 0 & 11 & 0 & 6 & 1 & 1 & 20 & 8 & 2 & 0 & 0 & 19 & 10 & 20 & 17 & 2 & 6 & \\
\hline フランス & 42 & 14 & 5 & 15 & 1 & 0 & 0 & 0 & 0 & 0 & 0 & 14 & 0 & 7 & 0 & 0 & 0 & 0 & 24 & 0 & 0 & 4 & chr 1 \\
\hline イタリー & 36 & 9 & 1 & 0 & 15 & 0 & 0 & 0 & 2 & 6 & 0 & 0 & 0 & 5 & 4 & 0 & 2 & 7 & 8 & 5 & 0 & 7 & \\
\hline 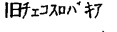 & 34 & 25 & 0 & 27 & 0 & 3 & 0 & 1 & 1 & 1 & 0 & 1 & 0 & 0 & 0 & 0 & 0 & 2 & 3 & 0 & 0 & 2 & der 3 \\
\hline ブラジル & 34 & 3 & 27 & 0 & 2 & 0 & 0 & 0 & 2 & 0 & 3 & 0 & 0 & 0 & 0 & 0 & 0 & 0 & 31 & 0 & 0 & 0 & dir 26 \\
\hline & 33 & 31 & 0 & 32 & 0 & 0 & 0 & 0 & 0 & 0 & 0 & 1 & 0 & 0 & 0 & 0 & 0 & 1 & 1 & 0 & 0 & 0 & \\
\hline ブルガリア & 30 & 6 & 0 & 4 & 6 & 8 & 0 & 3 & 0 & 1 & 1 & 1 & 0 & 1 & 3 & 0 & 3 & 2 & 14 & 0 & 0 & 1 & \\
\hline ポーランド & 30 & 17 & 0 & 1 & 0 & 0 & 0 & 0 & 1 & 21 & 6 & 1 & 0 & 0 & 0 & 0 & 1 & 4 & 9 & 0 & 0 & 0 & \\
\hline コードジフール & 26 & 17 & 26 & 0 & 0 & 0 & 0 & 0 & 0 & 0 & 0 & 0 & 0 & 0 & 0 & 0 & 0 & 0 & 9 & 0 & 0 & 0 & dir 9 \\
\hline カイアナ & 26 & 0 & 26 & 0 & 0 & 0 & 0 & 0 & 0 & 0 & 0 & 0 & 0 & 0 & 0 & 0 & 0 & 0 & 26 & 0 & 0 & 0 & che 26 \\
\hline スエーテン & 26 & 20 & 0 & 20 & 0 & 0 & 0 & 0 & 0 & 1 & 0 & 0 & 0 & 0 & 0 & 0 & 5 & 6 & 0 & 0 & 0 & 0 & \\
\hline パキスタン & 24 & 0 & 4 & 0 & 4 & 0 & 0 & 0 & 1 & 12 & 0 & 0 & 0 & 0 & 0 & 2 & 0 & 0 & 18 & 1 & 0 & 2 & \\
\hline ヴェトナム & 24 & 6 & 14 & 0 & 0 & 2 & 0 & 4 & 0 & 1 & 0 & 0 & 0 & 2 & 0 & 0 & 1 & 0 & 9 & 0 & 0 & 12 & \\
\hline ベルギー & 2 & 1 & 0 & 1 & 0 & 0 & 0 & 0 & 0 & 1 & 7 & 8 & 3 & 0 & 0 & 0 & 2 & 16 & 10 & 0 & 0 & 2 & \\
\hline カナダ & 22 & 12 & 0 & 2 & 0 & 0 & 0 & 0 & 1 & 0 & 0 & 4 & 0 & 8 & 0 & 2 & 4 & 7 & 2 & 1 & 1 & 2 & \\
\hline デンマーク & 22 & 20 & 0 & 22 & 0 & 0 & 0 & 0 & 0 & 0 & 0 & 0 & 0 & 0 & 0 & 0 & 0 & 0 & 0 & 1 & 0 & 1 & \\
\hline イラク & 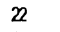 & 2 & 2 & 7 & 6 & 0 & 0 & 0 & 0 & 2 & 0 & 0 & 0 & 0 & 0 & 0 & 5 & 0 & 17 & 3 & 0 & 0 & \\
\hline オーストリア & 20 & 17 & 0 & 12 & 6 & 0 & 0 & 0 & 0 & 1 & 0 & 0 & 0 & 1 & 0 & 0 & 0 & 1 & 2 & 0 & 0 & 0 & \\
\hline 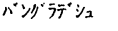 & 16 & 3 & 3 & 0 & 0 & 0 & 0 & 0 & 0 & 3 & 0 & 0 & 0 & 0 & 1 & 3 & 6 & 2 & 6 & 0 & 0 & 2 & \\
\hline フィンランド & E 11 & 6 & 0 & 4 & 1 & 0 & 6 & 0 & 0 & 0 & 0 & 0 & 0 & 0 & 0 & 0 & 0 & 2 & 3 & 0 & 0 & 0 & \\
\hline インドネシア & 11 & 1 & 6 & 0 & 0 & 0 & 0 & 3 & 0 & 1 & 0 & 0 & 0 & 0 & 0 & 0 & 1 & 1 & 9 & 0 & 0 & 0 & \\
\hline 䫒国 & 11 & 2 & 2 & 1 & 0 & 0 & 0 & 2 & 0 & 0 & 0 & 0 & 0 & 0 & 0 & 0 & 6 & 4 & 1 & 2 & 0 & 3 & \\
\hline タイ & 9 & 1 & 4 & 0 & $\theta$ & 0 & 0 & 1 & 0 & 0 & 2 & 1 & 0 & 1 & 0 & 0 & 0 & 0 & 7 & 1 & 0 & 0 & \\
\hline t-자기 & 7 & 3 & 0 & 0 & 0 & 0 & 2 & 1 & 0 & 4 & 0 & 0 & 0 & 0 & 0 & 0 & 0 & 0 & 0 & 0 & 0 & 4 & \\
\hline ハンガリー & 6 & 1 & 3 & 0 & 1 & 1 & 0 & 0 & 0 & 0 & 1 & 0 & 0 & 0 & 0 & 0 & 0 & 0 & 2 & 2 & 0 & 1 & \\
\hline アルビンチン & 6 & 0 & 0 & 0 & 1 & 0 & 0 & 0 & 0 & 2 & 0 & 0 & 0 & 3 & 0 & 0 & 0 & 3 & 2 & 0 & 1 & 0 & \\
\hline カメルーン & 4 & 1 & 4 & 0 & 0 & 0 & 0 & 0 & 0 & 0 & 0 & 0 & 0 & 0 & 0 & 0 & 0 & 0 & 3 & 0 & 0 & 0 & dr 3 \\
\hline ミャンマー & 4 & 1 & 2 & 0 & 0 & 0 & 0 & 0 & 0 & 1 & 0 & 0 & 0 & 0 & 0 & 1 & 0 & 0 & 3 & 0 & 0 & 0 & \\
\hline ブヘキナプ゙ & 3 & 3 & 3 & 0 & 0 & 0 & 0 & 0 & 0 & 0 & 0 & 0 & 0 & 0 & 0 & 0 & 0 & 0 & 0 & 0 & 0 & 0 & \\
\hline コスタリカ & 3 & 0 & 2 & 0 & 0 & 0 & 0 & 0 & 0 & 1 & 0 & 0 & 0 & 0 & 0 & 0 & 0 & 0 & 3 & 0 & 0 & 0 & \\
\hline エジプト & 3 & 0 & 0 & 0 & 0 & 0 & 0 & 0 & 1 & 0 & 0 & 0 & 0 & 0 & 0 & 0 & 2 & 0 & 3 & 0 & 0 & 0 & \\
\hline モンゴル & 3 & 2 & 0 & 0 & 3 & 0 & 0 & 0 & 0 & 0 & 0 & 0 & 0 & 0 & 0 & 0 & 0 & 0 & 1 & 0 & 0 & 0 & \\
\hline ナイジェリア & 3 & 2 & 1 & 0 & 0 & 0 & 0 & 0 & 0 & 0 & 0 & 0 & 0 & 0 & 0 & 0 & 0 & 0 & 1 & 0 & 0 & 0 & \\
\hline フィリッピン & 3 & 0 & 3 & 0 & 0 & 0 & 0 & 0 & 0 & 0 & 0 & 0 & 0 & 0 & 0 & 0 & 0 & 0 & 3 & 1 & 0 & 0 & \\
\hline スリランカ & 3 & 0 & 1 & 0 & 0 & 0 & 0 & 0 & 0 & 1 & 0 & 0 & 0 & 0 & 0 & 0 & 1 & 0 & 3 & 0 & 0 & 0 & \\
\hline & 2 & 1 & 0 & 1 & 1 & 0 & 0 & 0 & 0 & 0 & 0 & 0 & 0 & 0 & 0 & 0 & 0 & 0 & 1 & 0 & 0 & 0 & \\
\hline ギリシャ & 2 & 0 & 0 & 1 & 1 & 0 & 0 & 0 & 0 & 0 & 0 & 0 & 0 & 0 & 0 & 0 & 0 & 0 & 1 & 1 & 0 & 0 & \\
\hline ケニア & 2 & 0 & 0 & 0 & 0 & 0 & 0 & 0 & 0 & 2 & 0 & 0 & 0 & 0 & 0 & 0 & 0 & 0 & 2 & 0 & 0 & 0 & \\
\hline ノルウエー & 2 & 2 & 0 & 2 & 0 & 0 & 0 & 0 & 0 & 0 & 0 & 0 & 0 & 0 & 0 & 0 & 0 & 0 & 0 & 0 & 0 & 0 & \\
\hline セネガル & 2 & 0 & 2 & 0 & 0 & 0 & 0 & 0 & 0 & 0 & 0 & 0 & 0 & 0 & 0 & 0 & 0 & 0 & 2 & 0 & 0 & 0 & ahr 2 \\
\hline ウクライナ & 2 & 0 & 0 & 1 & 0 & 0 & 1 & 0 & 0 & 0 & 0 & 0 & 0 & 0 & 0 & 0 & 0 & 0 & 0 & 0 & 0 & 1 & \\
\hline アルジェリア & 1 & 0 & 0 & 0 & 0 & 0 & 0 & 1 & 0 & 0 & 0 & 0 & 0 & 0 & 0 & 0 & 0 & 0 & 1 & 0 & 0 & 0 & \\
\hline ギニアビサウ & 1 & 0 & 1 & 0 & 0 & 0 & 0 & 0 & 0 & 0 & 0 & 0 & 0 & 0 & 0 & 0 & 0 & 0 & 1 & 0 & 0 & 0 & dr 1 \\
\hline マダガスカル & -1 & 1 & 1 & 0 & 0 & 0 & 0 & 0 & 0 & 0 & 0 & 0 & 0 & 0 & 0 & 0 & 0 & 0 & 0 & 0 & 0 & 0 & \\
\hline ポルトガル & 1 & 0 & 1 & 0 & 0 & 0 & 0 & 0 & 0 & 0 & 0 & 0 & 0 & 0 & 0 & 0 & 0 & 0 & 1 & 0 & 0 & 0 & \\
\hline スイス & 1 & 0 & 0 & 0 & 1 & 0 & 0 & 0 & 0 & 0 & 0 & 0 & 0 & 0 & 0 & 0 & 0 & 0 & 1 & 0 & 0 & 0 & \\
\hline トーゴー & 1 & 1 & 1 & 0 & 0 & 0 & 0 & 0 & 0 & 0 & 0 & 0 & 0 & 0 & 0 & 0 & 0 & 0 & 0 & 0 & 0 & 0 & \\
\hline 科筷合計" & 1911 & 559 & 372 & 262 & 177 & 49 & 44 & 55 & 24 & 156 & 212 & 269 & 20 & 48 & 27 & 36 & 163 & 318 & 810 & 64 & 18 & 177 & drr 95 \\
\hline 雪始合言十 & 1897 & 567 & 341 & 261 & 177 & 49 & 43 & 58 & 24 & 156 & 211 & 265 & 20 & 48 & 27 & 36 & 151 & 319 & 810 & 64 & 18 & 175 & $d v 64$ \\
\hline
\end{tabular}

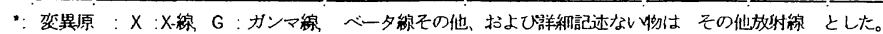

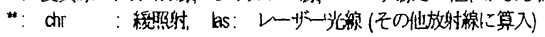

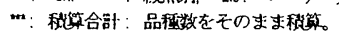

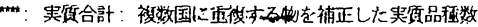


分野内では $83 \%$ となっている11,2)。その基礎と なっているわが国の突然変異法による各作物種 の品種については, 農水省の農業生物資源研究 所放射線育種場が取り継めてくれている。一般 に放射線照射等で誘発された突然変異系統をそ のまま品種として採用する場合を直接利用品種, 突然変異体を交配親として利用した場合を間接 利用品種として扱っている。IAEA の担当者も 当初に突然変異体が得られなければその後の展 開はないとの考え方で支持している。ヨーロッ パでは旧チェコスロバキアで1965年に原品種 Valticky の X 線照射で育成された醸造用のオ オムギ品種「Diamant」は当時の鉄のカーテン を超えて，欧州中部のビール文化圈で100近い 子孫品種が育成され, その生産高も $90 \%$ に達し ている15)。小国土ながら花き類の実績で世界の 第 4 位にあるオランダの唯一の穀物であるオオ ムギ突然変異品種「Prisma」は，チェコスロ バキアの Diamant がドイッで交配されてでき た Trumpf を使った交配による品種である13)。 一般に農作物では一つの品種を育成するには 数年の期間がかかるが，それらの栽培される期 間，つまり品種の寿命は決して長いものではな い。前述の経済効果の調査では突然変異品種の 普及度, 収穫量の調查と価額換算は難しい作業 だった。幸い担当者の努力で国内の各都道府県 の主要栽培品種のリストがインターネット情報 で得られた。それを表 2 に示す1)。

現在の日本の稲作では良食味で有名なブラン ドであるコシヒカリの圧倒的な優位が他の新し い品種の普及を抑え込んでいる弊害が読みとれ る。例外的に 50 年にもなる長寿命のコシヒカリ 自体は確かに優れた食味の品種であるが，農家 にとっては栽培の容易な品種ではない。その影 響下でいろいろな欠点を改良した突然変異品種 は残りのシェアを一般品種と分け合っていると いう状況である。

1980年代になって, DNA, 分子遺伝学研究 の重要な成果として, 遺伝子の詳細な構造が解 明され16), 突然変異の機構と結果が明らかにな
ってきた17)-19)。誘発できる突然変異は正常な 遺伝子の不活性化，強く言えば破壊であり，そ の結果は劣性遺伝するものがほとんどである。 活性を回復するような優性突然変異は期待でき ない。このことが明確になってきたことによっ て，劣性形質や少性遺伝子が求められるときは 突然変異法, 優性形質・遺伝子が求められる場 合は形質転換法（GMO p遺伝子組換え）によ るべきであるという役割がはっきりしてきたの はこの 20 年ほどの間の大きな収穫といえよう20)。 これら二つの技術は従来どおり作物育種の主要 手段である交配育種を支える補助技術として互 いに相補いながら目的によって選択すべき技術 である。最近の知見としては温度感受性雄性不 稳のような遺伝子生産物の三次元構造の解明が 望まれる分野も出てきている21)。

放射線技術の経済効果を調べるというプロジ エクトでは，第 2 年度に国際比較をすることに なり，米国を対象国とすることになった。この 調查に当たっては農作物の突然変異育種の分野 では育種技術の傾向も調べることになった。そ の結果では米国の主要農作物の育種に関しては 突然変異系と形質転換系（米国で GMO，日本 では遺伝子組換え）についてははっきりと 2 極 化していることがわかってきた。その傾向を表 3 に示す 3 )。

他殖性作物で，企業生産によるハイブリッド 種子を用いた栽培が普及しているトウモロコシ の場合は，なぜか電離放射線では好ましい突然 変異体の誘発・選抜ができない17),18)。しかし 大豆の場合は各種脂肪酸の含有量の変更や酵素 活性の抑制が可能など22)-24)，突然変異育種は 難しいものではない。だが米国での 2 極化の傾 向は品種数的には明確に見られる現象であっ だ),ウ。

わが国の場合は世界でも数少なくなったガン マーフィールドを持つ放射線育種場がこの分野 の中心としての役割を果たしている。ガンマー フィールドは同種のものが米国のように放射線 生物学研究用のもの，あるいは国外技術に依存 
表 2 各都道府県における作付け水稲品種

出典:http://unw.ne.jp/asahi/kiichiro/hp/info_p2.html より改变

\begin{tabular}{|c|c|c|c|c|c|c|c|c|}
\hline 搷海 & ะらら397 & 中をひかり & 中きまる & 然言 125量 & & & & \\
\hline 费基 & วがるロロマ & あをたこまち & Down a & $60.10 \mathrm{~m}$ & 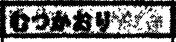 & sustos & & \\
\hline 雚手 & Uとめぽn & あきたこまら & ササニシキ & 申めめさんさ & & & & \\
\hline 量证 & Uとめほれ & ササニシキ & まなむすめ & こころまち & おさきにいい & コシヒかリ & & \\
\hline 狄田 & あきたこまち & ササニシキ & Uとめほほn & & & & & \\
\hline 山韧 & コシヒが & は元め媇 & ササこシキ & ひとめほれ & どまんなか & あをたこ末ち & はなの望 & \\
\hline 青禹 & コシヒが & ひとあぼn & ササニシキ & あきたこま & 日本睛 & しょうで & 初星 & \\
\hline 英茧 & コシヒかリ & 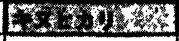 & F⿻コシキ & まなむす & あたた二まち & 初星 & & \\
\hline 霟木 & コシヒが & ひとぬぼれ & 晴れすがた & 塹の光 & 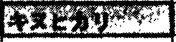 & 初星 & & \\
\hline 帮馬 & コシヒが & $=30(\pi 4$ & Uとめぼれ & 50光 & & & & \\
\hline 满王 & コシヒかリ & 月の光 & Pキニシキ & 志か力空 & 日本睛 & & & \\
\hline 千㟟 & コシヒかリ & ふさおとめ & 彻暴 & H.t.o) & 八+t女n & あさたこまち & & \\
\hline 部尞监 & Existwoy & アキニシキ & & & & & & \\
\hline 些渴 & コシヒか & 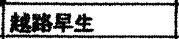 & Hト́ロキワt & ちせしまん & 仲をの精 & はししL昧 & 新溫里生 & \\
\hline 山 & コシヒが & 日本睡 & 八ナエ干ば; & 2年加 & & & & \\
\hline 石川 & コシヒが & ほほほほ营 & 能登ひから & tingen & & & & \\
\hline 整井 & コシヒかリ & 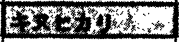 & 日本潭 & ハナエチぜ & & & & \\
\hline 山粟 & コシヒか & ひとめほれ & 日本睡 & こいこころ & & & & \\
\hline 晨箠 & コシヒか & しなのこがね & ドロキワセ & あをたこまち & ながのほ方れ & 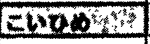 & 幽啨 & \\
\hline 坡皋 & コシたかり & ハツシモ & 日本腈 & ヤマヒカリ & み.のにこLき & あたた二まち & & \\
\hline 1 & コシヒかり & (t) wow & 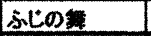 & & & & & \\
\hline 知 & コシヒか & 英の里 & Ensto & chen & towsonitsy & あきたこまち & & \\
\hline 三童 & コシヒカリ & 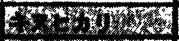 & Trastow & あをたこまち & 書公 & †マヒガ & & \\
\hline 些望 & コシヒカか & 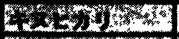 & 日本䁪 & 滋贺 60 量 & ハナエチゼン & & & \\
\hline 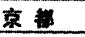 & コシヒかリ & 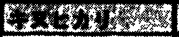 & Drox \& & 日本䀧 & $\mathrm{CHLWM}$ & & & \\
\hline 大 5 & 槽々 & E/tカI & E. & & & & & \\
\hline 兵戠 & コシヒか & ERThom & 日本䁖 & あしまる & 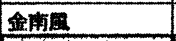 & ヤマE゙コ & ヒ片品 & *x<n \\
\hline 余良 & ホウレイ & アキツ木 & アスカミハリ & ヒ代が & Ax<xu: & & & \\
\hline 驾斯山 & tescrsots & & & & & & & \\
\hline 取 & コシヒ加 & ひとめぼれ & AxEtiy & サマホウシ & 日本啨 & おまちかね & TrEか & \\
\hline 粪 & コシビか & とをぬを35 & Fri! & 日本睡 & & & & \\
\hline 山 & コシヒが & 朝日 & アケボ & あさたこ志ら & 声监の基 & おとめこころ & 日本丵 & \\
\hline 広鹿 & コシヒが & 切星 & あをたこまち & あきろまん & 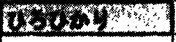 & & & \\
\hline 山口 & コシヒかリ & ヤマホウン & trots's & 腈る万 & せとむすめ & & & \\
\hline 锿 & コシヒが & Axt $t y_{2}$ & 日本睛 & ヘナエチゼン & & & & \\
\hline 香川 & コシヒかり & texis & 2sidl & Eルか & コガネマサリ & & & \\
\hline 监 & コシヒが & こいこころ & 昖山三井 & あきたこまち & & & & \\
\hline 㜔 & コシヒかリ & ナッルカ加 & 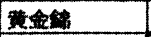 & あをたこまち & & & & \\
\hline 穞闌 & コジかり & $x<L$ & ヒ化り & Exw & くく星生 & fatesus: & ツクシホマレ & \\
\hline 传買 & コシヒかリ & 俈賀 1 量 & E代 & 奶かね空 & あこがれ & L椺以 & 日本啨 & \\
\hline 唇 & コシヒかり & ヒ化加 & か以の管 & シンレ1 & 日本睛 & & & \\
\hline 酯本 & コシヒカり & Eルか & Z化少 & 㢣いずみ & 森のくまさん & あさげしき & つふ心より & \\
\hline 大分 & Esかか & 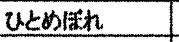 & ヒルが & こいこころ & クジタ & & & \\
\hline 宣出 & コシヒかリ & ヒルか & 巳らり密謧 & ESE $x^{2}$ & か山の葓 & シナ三比少 & & \\
\hline 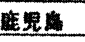 & コシヒか & ヒハカか & か以の斟 & Eンル & シナミヒかり & & & \\
\hline
\end{tabular}

するものであるために，維持が困難になって閉 鎖が続き，現在では中国の成都にあるものとわ が国のものが残っている程度である。わが国の 場合は当初から国内技術で設計され25)，日本ア イソトープ協会の協力もあって, 隔年の線源更 新も続けられてきている。またその目的も長期 にわたる作物育種用という性格から現在もなお
運用されているものである。周辺環境にスカイ シャインなどでごくわずか漏洩している散乱線 を低減する努力は引き続き行われており，黒斑 病耐病性の二十世紀梨品種の「ゴールド二十世 紀」をはじめとする多くの突然変異育種の成果 を生み出しつつある26)-30)。なお，同場主導で 行われているガンマーフィールド・シンポジウ 
表 3 米国主要作物における育種方法の傾向

\begin{tabular}{|c|c|c|c|c|}
\hline 作物 & 育種機関 & 主要目的方法 & 農家の傾向 & 消費者の動向 \\
\hline \multirow[t]{2}{*}{ トウモロコシ } & 企業系 & 蛽虫耐性 $\mathrm{GMO}$ (BT 遺伝子) & 売れない物には困惑 & 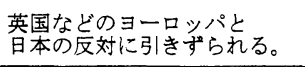 \\
\hline & USDA 系 & 一般特性 除雄処理は機珹による & $\begin{array}{l}\text { 䍜病性の雄性不稔 } \\
\text { 素素に抵抗感 }\end{array}$ & GMO でなければ受け入れる。 \\
\hline 大豆 & 企業系 & 除草剤耐性 GMO(耐性遺伝子) & $\begin{array}{l}\text { 事実上好感。 } \\
\text { 売れなくはば使わぬ。 }\end{array}$ & $\begin{array}{l}\text { 外国での反対に引きずられる } \\
\text { 可能性あり。 }\end{array}$ \\
\hline 綿 & 企業系 & 虫害耐性 $\mathrm{GMO}$ (BT 遗伝子) & 事実上好感 & 食品でなければ無関心だろう。 \\
\hline トマト & 企業系 & 日保ち性 GMO(分解醭素抑制) & 事実上好感 & 無関心? \\
\hline 稲 & USDA 采 & $\begin{array}{l}\text { 雑草抑制 抑制系統選抜(生態学的) } \\
\text { 倒防止等 突然変異法 }\end{array}$ & $\begin{array}{l}\text { (未発表) } \\
\text { 実續に好感 }\end{array}$ & $\begin{array}{l}\text { (未発表だが自然食品的) } \\
\text { 実續に好感 }\end{array}$ \\
\hline 小麦 & USDA 系 & $\begin{array}{c}\text { 病害抵抗性 以前は放射線誘発転座 } \\
\text { 最近は自然転座法 }\end{array}$ & $\begin{array}{l}\text { 当時は好感 } \\
\text { 閴なし }\end{array}$ & $\begin{array}{l}\text { 当時は問題なし } \\
\text { 問題なし }\end{array}$ \\
\hline 大麦 & $\begin{array}{l}\text { 大学系 } \\
\text { 歯の例 }\end{array}$ & $\begin{array}{l}\text { 代謝産物制御 突然変異法 } \\
\text { 代澍産物制御 突然法 }\end{array}$ & $\begin{array}{l}\text { 䦗題なし } \\
\text { 題なし }\end{array}$ & $\begin{array}{l}\text { 䦗題なし } \\
\text { 閴なし }\end{array}$ \\
\hline
\end{tabular}

ムは平成13年で第40回となる。これも長寿のシ ンポジウムであるエ)。

最近のこの分野での主な活動にイオンビーム 照射がある。植物種子のイオンビーム照射が可 能な加速器がわが国でも使えるようになり, 新 しい変異誘発のための照射手段となってきた。 高 LET 放射線については，中性子照射を含め て，1950年代から70年代にかけての放射線生物 学全盛期に多くの基礎研究がなされている。こ れらの先導的な研究を参考にしつつ新しい遺伝 子構造等の知見に合わせた新しい問題点の発掘, たとえば遺伝子の抽出のための欠失型突然変異 の誘発などに効果的な利用が望まれる。

\section{2. 不好虫放铜法}

放射線照射の効果の大きなものの例として, 不妊虫放飼法 (SIT : Sterile Insect Technique) による特定害虫の根絶駆除が挙げられる。これ は次のような方法によるものである。

\section{○要素}

（1）成虫の筋肉や神経はほとんど細胞分裂 しないので放射線感受性が低く, 行動への影響 が少ない。

（2）精巣・精子等はさかんに細胞分裂をす るので放射線感受性が高く, 受精卵に重い生育 障害が出る。

（3）雄は雌を求めて飛び回る（できれば雄
だけを使いたい）ので探索成功率が高い。

（4）生じた受精卵は死滅するため根絶に至 る。

\section{一実施法}

（1）前もって個体数を抑え込む（薬剤，フ エロモン誘引法など）。

（2）多量の不妊化虫を「標識を付けて」放 してやる。

（3）（標識のついていない）自然集団の大 きさをトラップ法で調べ続ける。

（4）根絶宣言に至る。

・結果とその後の手当

（1）その種のみの根絶が可能。

（2）周辺地域からの再流入防止への対策が 必要 (予想流入地点での事業継続)。

この方法は自然交配の起こる同一種に限定さ れる根絶法であり，無差別の殺虫剂散布のよう にほかの有益な昆虫類を損なうことなく，特定 の害虫の完全絶滅が可能な技術である31)-36)。 ただ，その実施に当たっては当該害虫を大量に しかも安全に飼育増殖する必要があり, 地理的 には少しずつ進められる島嶼構造が望ましいな どの条件があり，プロジェクトとしても国家的， あるいは国際的な大きな規模が必要である。わ が国では表 4 のように，まず小笠原のミカンコ ミバエで成功を収めた後，奄美諸島と沖縄諸島 で進められ，1993年には最西端の八重山群島ま 
で根絶を終わり，沖縄でのウリミバエの根絶は 終わったのである34),35)。しかし現在も隣接す る台湾からの再侵入に備えて，沖縄本島にある ウリミバエ増殖・不妊化工場は引き続き維持さ れていて, 最先端の島では不妊虫放飼が続いて いるとのことである。この方法は効果は絶大で あり，環境にも優しい優れた技術であるが，実 施が大規模になるものの，当該地域に限定され ることなどから，一般にはあまり知られないの ではないだろうか。なおこの不妊虫放飼法につ いては，放射線利用振興協会のデータベースに も詳しく収録されているオ。

この技術は最初は米国の家畜害虫である肉バ エ類のラセンウジバエに，カリブ海のキュラソ 一島で実施され37),38)，成功を収めた後，米国 南部のフロリダ州, 続いてテキサス・アリゾナ 両州で根絶を終わりオ)，メキシコ等との国際協 力の下で次第に南下して現在はパナマ地峡部分 に最前線の不妊虫工場を設置することになって いる。筆者には IAEA 勤務中に突然変異育種 の推進事業でパナマに出張した際についでにそ の予備交渉を依頼されたということもあった。

新大陸ラセンウジバエと呼ばれるこのニクバ エについては, 1988年 3 月に, 突然北アフリカ のリビアに侵入していることがわかり，そのま ま放置して，アフリカ大陸に深く分布すること になればアフリカの貴重な野生動物が失われる ことになるとして，急遽FAOを中心にIAEA を含む大きな国際プロジェクトが発足し，メキ シコの不妊虫工場から照射された不妊虫を大西 洋を越えて空輸し，1992年には完全に排除する ことができている39)。
この技術は $\mathrm{FAO} / \mathrm{IAEA}$ 共同部門の担当課 でも引き続き推進しており, ツエッエバエと地 中海ミバエについて実施および基礎研究を進め ている。ツエッエバエはアフリカ大陸の中央部 に分布し，血液に寄生するトリパノソーマによ る家畜の眠り病を媒介するアブの一種であるが， 広い大陸の中にあっても，その生態的分布が島 嶼的になっていることから漸進的駆除が可能と 考えられている40)。IAEA 勤務を終えた带国後 に，あらためてIAEA からの依頼で行った夕 ンザニアへの出張ではこの不妊化用の $\gamma$ 線照 射装置の余剩品を作物育種用に転用できるかど うかを調べることになっていた。海岸部のタン ガの町にある研究所では小規模ながら家畜の血 液を使ったツエッエバエの増殖と $\gamma$ 線照射に よる不妊化が行われており, タンガの沖に浮か ぶザンジバルの島ではすでに根絶が進んでいる とのことであった40)。

タンザニア内陸部の相手方農業試験場訪問時 には週末が挟まったことから，あまり遠くない タランギリ国立公園に自費でサファリ旅行をし たが，そこではこれらのケニアやタンザニアの 国立公園の野生動物は実はツエッエバエによっ て保護されているという生態学的な現象に接す ることができた。この地域の周辺ではマサイ族 が放牧生活をしている。国立公園としてカモシ カ, キリン(ジラフ), ゾウ, ヒヒなどの野生動 物がいる場所では，空を開けたサファリ用の自 動車の中に常時10匹ほどのツエッエバエが入り 込んでいるほど，この虫の生息数は多かった。 公園の案内書によると, 野生の動物はツエツエ バエあるいはトリパノソーマ感染症に抵抗性で

表 4 放射線利用によるミバエ根絶事業1)

\begin{tabular}{|c|c|c|}
\hline & ミカンコミバエ & ウリミバエ \\
\hline 沖縄県 & $\begin{array}{l}\text { S } 52 \sim \mathrm{S} 61 \\
\text { (雄除去法) }\end{array}$ & $\begin{array}{l}\mathrm{S} 47 \sim \mathrm{H} 5 \\
\text { (不妊虫放飼法) }\end{array}$ \\
\hline $\begin{array}{c}\text { 奄美群島 } \\
\text { (鹿児島県大島支庁) }\end{array}$ & $\begin{array}{c}\text { S } 43 \sim \mathrm{S} 55 \\
\text { (雄除去法) }\end{array}$ & $\begin{array}{l}\text { S } 56 \text { ～H元 } \\
\text { (不妊虫放飼法) }\end{array}$ \\
\hline $\begin{array}{c}\text { 小笠原諸島 } \\
\text { (東京都小笠原村) }\end{array}$ & $\begin{array}{l}\mathrm{S} 50 \sim \mathrm{S} 60 \\
\text { (不妊虫放飼法) }\end{array}$ & - \\
\hline
\end{tabular}

筆者註 : 雄除去法とはフェロモンに殺虫剤を加えて、雄虫を誘引除去する方法である。 
あるという。不妊虫放飼法による害虫の根絶は 強力な技術であるが，仮にこの国立公園で実施 され，ツエツエバエが駆除されたときには，相 当に強力な法的規制によってマサイの人々の放 牧侵入を防がなければ, 貴重な野生動物までも 駆除してしまうことになりかねない。強力な技 術は副作用も十分に考えておかねばならない。

IAEA ではウィーンから50キロほどのザイベ ルスドルフに研究所を持っており，そこでは不 妊虫放飼法についても地中海ミバエで雄雌の分 別法の開発を進めている。不妊虫放飼法で効果 的なのは雄虫であり, 一般にほほ半数生まれて くる雌を早期に排除することができれば，飼育 飼料の節約や，放飼効率の改善などに好ましい。 この雌雄分別は蛹の色での機械的な弁別も試み られたようだが41)，現在では幼虫時期の飼育温 度の感受性が違う遺伝子を性染色体に転座させ て，単純に温度処理で選抜できるようになって いる42)。ただそのような効率化を図っても，地 中海沿岸は横に連続する広い地域であり, 困難 なものであろう。

なお，旧科学技術庁予算による東アジア地区 の原子力技術支援プロジェクトのなかの農業分 野は，当初にまずこの不妊虫放飼法で始まって いる。しかし，対象が大陸系の地域であったた めと, 対象虫の大規模増殖に費用がかかるなど 実施が難しく，情報交換にとどまったようであ
る43),44)。この国際協力では続いて突然変異育 種が取り上げられ，情報自体が効果的であるこ の分野では 7 年を経て現在も継続中である。

\section{3. 食品照射}

わが国では各地に原子力発電所が建設・運用 され，その電力面でのシェアも相当に高いが, 原爆の被爆国であることと，一般市民の知識・ 意識レベルが高いこともあって，放射線アレル ギーという言葉も出るほどに食品照射には抵抗 感がある。しかし，現在世界の傾向は食品照射 容認に向かっており，照射容認線量の上限をは ずす動きまで伝えられている。これらの照射は 誘導放射能を誘起しない $\gamma$ 線，電子線，電子 線変換の X 線などによるものである。わが国 の場合，表 5 のように学術研究レベルでは，か なり以前に安全性が報告されており，実施を待 つばかりの状態となっているが，実際に行われ ているのは現在は北海道士幌におけるジャガイ モの発芽抑制照射のみである1，45)。

しかし米国では1997年に病原性大腸菌 O-157 污染による大量のハンバーガーのリコールがあ ったり，一般の食中毒の件数，被害者数も大き な值になるために，その改善策としての食品照 射が検討され，多くの果実類，鶏肉類，一般肉 類, 香辛料等の多くの品目について照射が認め られている3)。なお，わが国でも基礎的研究で

表 5 日本における食品照射特定総合研究結果の概要

\begin{tabular}{|c|c|c|c|c|c|c|c|c|c|}
\hline \multirow[t]{2}{*}{ 品目 } & \multirow[t]{2}{*}{ 照射目的 } & \multirow[t]{2}{*}{ 放射線の種類 } & \multirow[t]{2}{*}{ 線是 } & \multicolumn{4}{|c|}{ 揵全性試哈 } & \multirow{2}{*}{$\begin{array}{c}\text { 実施期間 } \\
\text { (年度 }) \\
\end{array}$} & \multirow[t]{2}{*}{ 備考 } \\
\hline & & & & 栄養武駼 & 慢性毒性試䀠会 & 世代試験 & 变異原試験 & & \\
\hline ジャガイモ & 発芽防止 & $\gamma$ 線 & $0.06-0.15 \mathrm{kGy}$ & 影謷なし & 影雲なし & 影謷なし & 影慗なし & $S 42-46$ & $\begin{array}{c}\text { 食品衛生法許可 } \\
\text { (S47)、 } \\
\text { 実用化 (S48) }\end{array}$ \\
\hline タマネキ & 発来防止 & $\gamma$ 線 & $0.02-0.15 \mathrm{kGy}$ & $" 1$ & $"$ & $"$ & $"$ & $S 42-46$ & 研究成果報告済 (S55) \\
\hline 米 & 殺虫 & $\gamma$ 線 & $0.2-0.5 \mathrm{kGy}$ & $"$ & $"$ & $"$ & $"$ & $S 42-46$ & 研究成果報告流 (S58) \\
\hline 小麦 & 殺虫 & $\gamma$ 線 & $0.2-0.5 \mathrm{kGy}$ & $"$ & $"$ & $"$ & $\prime \prime$ & $\$ 42-46$ & $"$ \\
\hline $\begin{array}{l}\text { ウインナー } \\
\text { ソーセージ }\end{array}$ & 殺菌 & $\gamma$ 線 & $3-5 k G y$ & $"$ & $"$ & $"$ & $"$ & $S 42-46$ & 研究成果報告済 (S60) \\
\hline カマボコ & 殺菌 & $\gamma$ 線 & $3 \mathrm{kGy}$ & " & $"$ & $"$ & " & $S 42-46$ & $" 1$ \\
\hline ミカン & 表面殺菌 & $\begin{array}{c}\text { 菓子線 } \\
(0.5 \mathrm{MeV}) \\
\end{array}$ & $1.5 \mathrm{kGy}$ & $"$ & $"$ & $"$ & $"$ & $S 42-46$ & 研究成果報告済 (S55) \\
\hline 実施機関 & \multicolumn{3}{|c|}{$\begin{array}{c}\text { 農水省研究機関、日本原子力研究所、 } \\
\text { 日本アイントープ協会 }\end{array}$} & $\begin{array}{c}\text { 厚生省予防衛生 } \\
\text { 研究所 }\end{array}$ & $\begin{array}{c}\text { 厚生省国立栄薏 } \\
\text { 研究所 }\end{array}$ & \multicolumn{2}{|c|}{ 厚生省予防御生研究所 } & $\begin{array}{c}\text { 食品檪品安全 } \\
\text { センター }\end{array}$ & \\
\hline
\end{tabular}


は容認方向の成果が出ている46)-49)。

最近では検疫処理に使われてきた燻蒸剤の臭 化メチルが世界的に使用禁止される方向にある ために，その代替手段としての食品照射が注目 されるようになってきている。熱処理を加える ことのできない生鮮果実類や生鮮肉類, また香 辛料などは包装のままで内部まで殺菌・殺虫で きる放射線照射法がすでに多くの国で認可され ている1),3。

香辛料の照射を認める国が多いのは，他に代 替技術がないことと, 食品としての摂取量がわ ずかな量に限られているためでもあろう。おそ らく日本でも輸入胡椒などの香辛料が突破口と なって, 生鮮果実類の輸出国からの照射済み食 品を受け入れざるを得ない状況になってゆくの ではないだろうか。臭化メチルによる燻蒸が米 国で禁止される期限は2004年末とされており3), それ以後は米国からのグレープフルーツ, オレ ンジ，レモンやサクランボなどの輸入果実は検 疫燻蒸が輸出地ではできなくなる。この臭化メ チルの世界的な規制はモントリオール議定書に よるものであり，わが国もそれに従うことにな る3)。幸いわが国の一般市民のこのような事項 の理解レベルは十分に高いと思われるので, 適 切な広報活動によって理解を先行させる必要が あるだろう。前述の放射線利用振興協会のデー
タベースには食品照射分野のデー夕も多数収録 されているので参考にされたいオ。

\section{ま と め}

生物学的, 農学的, 農業的分野における放射 線照射利用について, 三つの分野について述べ てきたが，それぞれに含む意味・意義は，そし て傾向・今後の展開の予想には違いがあるとし ても，いずれも引き続き注目すべき分野である。 突然変異育種では, 従来の電離放射線のほかに 化学変異原, さらには最近の研究の成果として, カルス培養を経ることによるレトロトランスポ ゾンの活性化によるいわば生物学的な変異誘発 も実用手段にもなりつつあり50),51), 放射線離 れが一部では進行している。また不妊虫放飼法 は適用可能な場面がそれほど広くないなどの制 約があるが, 食品照射については薬剤による燻 蒸法の代替技術として, 今後注目を要する分野 である。なお突然変異育種, 害虫根絶法, 食品 照射等についてはインターネット上の技術デー タベースも公開されているオ。

\section{文献}

1）調查報告書一放射線利用の経済規模 - 平成 11 年 度, 日本原子力研究所高崎研究所 (2000)

2）科学技術庁：放射線利用の経済規模 平成 11 年

表 6 食品照射を実用化している主な国と処理量 ${ }^{11}$

\begin{tabular}{|c|c|c|}
\hline 国名 & 食品類 & 処理量（トン/年） \\
\hline アルゼンチン & 香辛料、乾燥野菜 & 650 \\
\hline ベルギー & 香辛料、椧凍魚介類 & 19,000 \\
\hline カナダ & 香辛料、等 & 4,500 \\
\hline チリ & 香辛料、等 & 450 \\
\hline 中国 & ニンニク、香辛料、等 & 50,000 以上 \\
\hline フランス & 香辛料、鶏肉、等 & 20,000 以上 \\
\hline ハンガリー & 香辛料、等 & 1,000 \\
\hline インドネシア & 香辛料、等 & 500 \\
\hline イスラエル & 香辛料、等 & 1,200 \\
\hline 日本 & 馬鈴薯 & 15,000 \\
\hline 韓国 & 香辛料、朝鮮ニンジン粉末 & 3,000 \\
\hline オランダ & 香辛料、冷凍魚介類、鷄肉 & 20,000 以上 \\
\hline ポーランド & 香辛料、等 & 400 \\
\hline 南アフリカ & 香辛料、ニンニク、等 & 12,600 以上 \\
\hline タイ & 発酵ソーセージ、香辛料 & 100 \\
\hline イギリス & 病人食、香辛料 & 若干量 \\
\hline 米国 & 香辛料、果実、鶏肉、等 & 40,000 以上 \\
\hline
\end{tabular}


（広報用冊子）（2000）

3）調査報告書 - 放射線利用の経済規模 - 平成12年 度, 日本原子力研究所高崎研究所 (準備中) (2001)

4) Muller, H. J. : Artificial transmutation of the gene, Science, 66, 84-87 (1927)

5) Stadler, L. J. : Genetic effects of X-rays in maize, Proc. N. A. S. , 14, 69-75 (1928)

6) Stadler, L. J. : Mutations in barley induced by Xrays and radium, Science, 68, 186-187(1928)

7) Mutation Breeding Newsletter, No. 9-44, Joint FAO/IAEA Div. IAEA

8) Mutation Breeding Review, No. 3, Joint FAO/ IAEA Div. IAEA (1985)

9) Mutation Breeding Review No.12, Joint FAO/ IAEA Div. IAEA (2000)

10) Sato, H. : Since Reimei : Its use for rice breeding, Gamma-Field Symposia No.21, 1- 6(1982)

11) Kawai, T. and Amano, E.: Mutation Breeding in Japan, IAEA Symposia on Plant Mutation Breeding for Crop Improvement, (IAEA-SM-311 /110 P) Vol. 1, : 47-66 (1991)

12) Mutation Breeding Newsletter, No. 23, Joint FAO/IAEA Div. IAEA (1984)

13) Mutation Breeding Newsletter, No. 36, Joint FAO/IAEA Div. IAEA (1990)

14) Mutation Breeding Newsletter, No.35, Joint FAO/IAEA Div. IAEA (1990)

15）天野悦夫：海外における放射線育種一現状と将 来展望一，エネルギーレビュー，1996年10月号， 18 - 21(1996)

16) Klosgen, R. B., Gierl, A., Schwarz-Sommer, Z. and Saedler, H. : Molecular analysis of the waxy locus of Zea mays, Mol. Gen. Genet., 203, 237244(1986)

17) Mottinger, J. P. : The effects of X-rays on the bronze and shrunken loci in maize, Genetics, 64, 259-271 (1970)

18) Amano, E.: Genetic fine structure of induced mutant gene in cereals, Gamma-Field Symposia No.24, 81-96(1985)

19) Yatou, O. and Amano, E.: DNA Structure of Mutant Genes in the waxy Locus in Rice, IAEA Symposia on Plant Mutation Breeding for Crop Improvement, (IAEA-SM-311/110 P) Vol. 2, 385389 (1991)

20）天野悦夫：突然変異育種の成果と展望－突然変
異育種を巡る国際情勢と展望 (8), 農業技術, 55 (11), $514-518(2000)$

21) Maruyama, K., Araki, H., Kato, H. and Amano, E. : Enhancement of outcrossing habits of rice plant (Oryza sativa L.) by mutation breeding, Gamma Field Symposia No. 29, 11-25(1990)

22) Takagi, Y., Manun Hossain, A. B. M., Yanagita, T. and Kusaba, S. : High linolenic acid mutant in soybean induced by X-ray irradiation, Jpn. J. Breed. , 39, 403-409 (1989)

23) Hajika, H., Suda, I., Sakai, S. and Takahashi, M. : Gamma-ray Induction of a Mutant Soybean (Glycine $\max (\mathrm{L}$.$) Merrill) line Lacking All Seed$ Lipoxygenases, Gamma Field Symposia No. 35, 21-38(1996)

24) Takagi, Y., Manun Hossain, A. B. M., Yanagita, T., Kusaba, S., Matsueda, T. and Maruyama, A. : Linolenic acid content in soybean improved by $\mathrm{X}$ -ray irradiation, Agric. Biol. Chem., 54, 17351738(1990)

25）河原 清：ガンマーフィールドの線量分布およ び放射線の環境に及ほす影響に関する研究，放 射線育種場研究報告, 第 1 号, pp. 9 - 21 (1967)

26) Sanada, T. and Amano, E. : Induced Mutation in Fruit Trees, In "Somaclonal Variation and Induced Mutations in Crop Improvement”, Ed. S. M. Jain et al., pp. 401-419, Kluwer Academic Publ. Dordrecht (1998)

27) Masuda, T., Yoshioka, T., and Inoue, K.: Selection of Mutants Resistant to Black Spot Disease Using the AK-Toxin in Japanese Pears Irradiated with Gamma-ray, Gamma-Field Symposia No. 33, 91-102 (1994)

28) Masuda, T., Yoshioka, T., Inoue, K., Murata, K., Kitagawa, K., Tabira, H., Yoshida, A., Kotobuki, K. and Sanada, T. : Selection of mutants resistant to black spot disease by chronic irradiation of gamma-rays in Japanese pear 'Osanijisseiki', J. Jpn. Soc. Hort. Sci., 66, 85-92 (1997)

29）壽 和夫：21世紀の産地を作る有望品種 ナシ, 果実日本，54，46-50(1999)

30）伊藤祐司：突然変異育種の成果と展望一果樹に おける突然変異育種 $(9)$ - , 農業技術, 55(12), $565-569(2000)$

31）小山重郎：害虫を自滅させる防除法一不妊虫放 
飼法の歩み，化学と生物， 31，137－139(1993)

32）小山重郎：日本におけるウリミバエの根絶, 日 本応用動物昆虫学会誌, 38, 219-229(1994)

33）垣花廣幸：日本国内からのウリミバエ根絶, 放 射線と産業, No.62, 53 - 55(1994)

34）垣花廣幸：ウリミバエ不妊虫の大量増殖法の確 立による根絶事業の成功, 農業技術, 49, 7 - 10 (1994)

35）垣花廣幸：不妊虫放飼による害虫駆除，エネル ギーレビュー，1996年10月号，11-14(1996)

36）東京都労働経済局農林水産部：ミカンコミバエ の不妊化，小笠原諸島におけるミカンコミバエ 防除事業報告書, pp. 55-64(1986)

37) Knipling, E. F.: Possibility of insect control or eradication through the use of sexually sterile males, J. Econ. Ent ., 48 (4), 459-462 (1955)

38) Baumhover, A. H., Graham, A. J., Bitter, B. A., Hopkins, D. E., New, W. D., Dudley, F. H. and Bushland, R. C.: Screw-worm control through release of sterilized flies, J. Econ. Ent, 48 (4), 462466 (1955)

39) Gillman, H., Cunningham, E. P. and Sidahmed, A. E.: The new world screwworm eradication programme, North Africa 1988-1992, In “The new world screwworm Eradication Programme, North Africa 1988-1992”, FAO, Rome (1992)

40) Tanzanian tsetse Brief, Newsletter No. 1-4, IAEA, Vienna (1996)

41) Whitten, M. J. : Automated sexing of pupae and its usufullness in control by sterile insects, $J$. Econ. Ent ., 62 (1) , 272-273(1969)

42) Franz, G., Kerremans, P., Rendon, P. and Hendrichs, J. : Development and application of genetic sexing systems for the Mediterranean fruit fly based on a temperature sensitive lethal, In "Fruit Fly Pest, A World Assessment of Their Biology and Management”, Ed. B. A. McPheron and G. J. Steck, St. Lucia Press, 185191 (1996)

43）（社）日本原子力産業会議：夕イにおける SIT FS 委員会および現地調査, 平成 5 年度地域協力
構想調査報告書, pp. 55 - 63(1995)

44）（社）日本原子力産業会議：フィリッピンにおけ る $\mathrm{SIT} \cdot \mathrm{FS}$ 委員会および現地調査, 平成 6 年度 地域協力構想調査報告書, pp. 55 - 65（1996）

45）梅田圭司, 高野博幸, 佐藤友太郎：放射線によ るジャガイモの発芽抑制 (第 1 報)「男爵」および 「島原」の照射時期と発芽率, 日本食品工業学 会誌, 16(11),508(1969)

46) Juri, M. L., Ito, H., Watanabe, H. and Tamura, N. : Distribution of microorganisms in spices and their decontamination by gamma-irradiation, Agric. Biol Chem ., 50 (2), 347 (1984)

47）小林彰夫：放射線照射による香辛料の風味変化, 食品照射研究委員会研究成果最終報告書, p. 90 , 日本アイソトープ協会(1992)

48）坂本京子：ガンマ線照射スパイス・マンゴーの 変異原性, 食品照射研究委員会研究成果最終報 告書, p. 204, 日本アイソトープ協会（1992）

49) Prachasitthisak, Y., 伊藤 均: ガンマ線照射に よる鶏肉の貯蔵期間延長効果, 食品照射, 31, $1-3$ (1996)

50) Hirochika, H. : Regulation of Plant Retrotransposons and Their Use for Genome Analysis, Gamma-Field Symposia No. 34. 77-91 (1995)

51) Hirochika, H., : Retrotransposons of rice as a tool for forward and reverese genetics, In "Molecular Biology of Rice”. pp. 43-58, Ed. K. Shimamoto, Springer-Verlag, Tokyo (1999)

\section{情 報 源（2001年現在）}

ア） http : //www-infocris.iaea.org/MVD/（IAEA 変 異品種データベース)

イ）http://www.ars.grin.gov/cgi-bin（米国遺伝資 源データベース)

ウ) http : //www.enn.com/indepth/gmfood/index. asp（GMO 食品について（米国)）

エ）http://www.irb.affrc.go.jp（放射線育種場ホー ムページ)

オ）http://www.rada.or.jp（放射線利用振興協会ホ ームページ (データベース) 